\title{
Influences of nanoparticle zinc oxide on acutely isolated rat hippocampal CA3 pyramidal neurons
}

\author{
ZHAO Jingxia ${ }^{1}$, XU Lanju ${ }^{2}$, ZHANG Tao $^{1}$, REN Guogang ${ }^{3}$, YANG Zhuo $^{2} *$ \\ ${ }^{1}$ Key Laboratory of Bioactive Materials, Ministry of Education, College of Life Science; ${ }^{2}$ College \\ of Medicine, Nankai University, Tianjin 300071, China \\ ${ }^{3}$ Science and Technology Research Institute, University of Hertfordshire, Hatfield, Herts AL10 \\ $9 \mathrm{AB}, \mathrm{UK}$
}

\section{Correspondence for Proofs:}

Professor YANG Zhuo, College of Medicine, Nankai University, Tianjin 300071, China

Tel: 86-22-23504364

Fax: 86-22-23502554

Email: zhuoyang@ nankai.edu.cn 
Abstract: The effects of zinc oxide nanoparticles (nano- $\mathrm{ZnO}$ ) on the properties of voltage-dependent sodium, potassium currents and evoked action potentials were studied in acutely isolated rat hippocampal CA3 pyramidal neurons at postnatal ages of 10-14 days rats using the whole-cell patch clamp technique. The results indicated that: (1) In the present of final concentration of $10^{-4} \mathrm{~g} / \mathrm{ml}$ nano- $\mathrm{ZnO}$, the current-voltage curve of sodium current $\left(\mathrm{I}_{\mathrm{Na}}\right)$ was decreased, and the peak amplitudes of $\mathrm{I}_{\mathrm{Na}}$ were increased considerably from -50 to $+20 \mathrm{mV}(\mathrm{p}<0.05)$. Meanwhile, the inactivation and the recovery from inactivation of $\mathrm{I}_{\mathrm{Na}}$ were also promoted by the nano- $\mathrm{ZnO}$ solution $\left(10^{-4} \mathrm{~g} / \mathrm{L}\right)(\mathrm{p}<0.01)$. However, the steady-state activation curve of $\mathrm{I}_{\mathrm{Na}}$ was not shifted by the nano-ZnO. (2) The amplitudes of transient outward potassium current $\left(\mathrm{I}_{\mathrm{A}}\right)$ were increased by the nano- $\mathrm{ZnO}$ solution $\left(10^{-4} \mathrm{~g} / \mathrm{ml}\right)$, while the current-voltage curve of delayed rectifier potassium current $\left(\mathrm{I}_{\mathrm{K}}\right)$ was significantly increased from +20 to $+90 \mathrm{mV}$ ( $\mathrm{p}<0.05$ ). However, it is apparent that the nano- $\mathrm{ZnO}$ solution didn't shift the steady-state activation curve of $\mathrm{I}_{\mathrm{A}}$ and $\mathrm{I}_{\mathrm{K}}$, and neither had significant effects on the inactivation and the recovery from inactivation of $I_{A}$. (3) Peak amplitude and overshoot of the evoked single action potential were increased and half-width was diminished in the presence of the $10^{-4} \mathrm{~g} / \mathrm{ml}$ nano- $\mathrm{ZnO}$ solution $(\mathrm{p}<0.05)$. Simultaneously, a prolonged depolarizing current injection enhanced $(\mathrm{p}<0.05)$ repetitive firing evoked firing rate. These results suggested that $10^{-4} \mathrm{~g} / \mathrm{ml}$ nano- $\mathrm{ZnO}$ solution can lead to an enhancement in the current amplitudes of $\mathrm{I}_{\mathrm{Na}}$ and $\mathrm{I}_{\mathrm{K}}$ by increasing the opening number of sodium channels, delaying rectifier potassium channels, and enhancing the excitability of neurons, which lead to $\mathrm{Na}^{+}$influx and the accumulation of intracellular $\mathrm{Na}^{+}$, as well as $\mathrm{K}^{+}$efflux plus the loss of cytoplasmic $\mathrm{K}^{+}$. These may disturb the ionic homeostasis and the physiological functions of neurons.

Key words: zinc oxide nanoparticles (nano-ZnO); CA3 pyramidal neurons; sodium current $\left(\mathrm{I}_{\mathrm{Na}}\right)$; transient outward potassium current $\left(\mathrm{I}_{\mathrm{A}}\right)$; delayed rectifier potassium current $\left(\mathrm{I}_{\mathrm{K}}\right)$; action potential. 


\section{Introduction}

With the industrialization of nanotechnology, public exposure to nanoparticles will undoubtedly increase in the near future. Consequently, there has been rising concern over the biosafety of nanomaterials. Currently, there is increasing scientific evidence that these the physical and chemical properties of manufactured nanoparticles lead to an increase in bioavailability and toxicity (Nel et al., 2006). Toxicological studies have shown that nanoparticles could enter into the human body through several distinct routes including inhalation, ingestion, and dermal penetration. Subsequently they could elicit toxicological effects at different levels of biological systems. Recent experimental studies indicated that nanoparticles coated with thiamine surface ligands representing a transporter would cross the blood-brain barrier(Lockman et al., 2003), further, size and surface charges as well as coating all contribute to nanoparticle's ability to cross biological barriers (Lockman et al., 2004). And inhaled ultrafine particles via the olfactory neuronal pathway could enter into the central nervous system (CNS) of exposed animals (Oberdorster et al., 2004; Elder et al., 2006).

Nanostructures of $\mathrm{ZnO}$ have great potential applications in nanoelectronics, optoelectronics, field emission, light-emitting diodes, photocatalysis, nanogenerators, and nanopiezotronics due to their exceptional semiconducting, piezoelectric, and pyroelectric properties (Wang, 2008). And it can also be used in environmental remediation because of its high chemical catalytic and strong physical adsorption capability for elimination or degradation of pollutants in water or air (Jing et al., 2001). Additionally, nano- $\mathrm{ZnO}$ is also widely used commercially in dyes, paints, textiles, medical diagnosis, sunscreens and cosmetics (Yuranova et al., 2007; Serpone et al., 2007; Colvin, 2003). Current interest has been focused toward the application of nano- $\mathrm{ZnO}$ in biosensing because of its high isoelectric point (9.5), certain level of biocompatibility showing promising features on the use of $\mathrm{ZnO}$ as a biomimic membrane to immobilize and modify biomolecules (Kumar and Chen, 2008; Li et al., 2008 ). One of the distinctive properties of the nano $\mathrm{ZnO}$ is its heritage capability of antimicrobe (Zhang et al., 2007; Tam et al., 2008). Some researchers demonstrated that nanostructures of $\mathrm{ZnO}$ were toxic to varying degrees towards the bacteria (Zhang et al., 2007; Reddy et al., 2007; Nair et al., 2008; Heinlaan et al., 2008;), the aquatic biota or eco-relevant species (Adams et al., 2006; Franklin et al., 2007; Zhu et al., 2008;), the mammalian cells (Jeng and Swanson, 2006) and mammals (Sayes et al., 2007; Wang et al., 2008). Adverse effects were partly due to the result of the generation of reactive oxygen species (ROS)(Yamamoto et al., 2004; Ghule et al., 2006; Tam et al., 2008) or causing membrane damage through the direct nanoparticle-cell membrane wall interaction or generation of ROS (Brayner et al., 2006; Zhang et al., 2007; Reddy et al., 2007; Heinlaan et al., 2008) or release of zinc ions in the $\mathrm{ZnO}$ particle suspensions (Brunner et al., 2006; Franklin et al., 2007; Zhu et al., 2008; Heinlaan et al., 2008). Therefore, the toxicity mechanisms of nano- $\mathrm{ZnO}$ are still fully clear. 
Ion channels are transmembrane proteins that mediate passive transport of ions, and the channels underlie a broad range of the most basic biological processes, from excitation and signaling to secretion and absorption. Studies of ion channels provide useful and informative clues for understanding the biophysics and pharmacology of these important and ubiquitous membrane proteins. Ion channels in cell membrane are targets for many toxins and drugs. Much damage on the CNS was caused by interrupting the function of ion channels (Taylor and Meldrum, 1995; Denac et al., 2000; Judge et al., 2007). Action potentials are a fundamental property of excitable cells in the mammalian CNS. Opening of $\mathrm{Na}^{+}$channels caused a rapid depolarization of membrane potential and constituted the upstroke phase of the action potential (Denac et al., 2000). Meanwhile, $\mathrm{Na}^{+}$influx through voltage-sensitive $\mathrm{Na}^{+}$channels has been implicated to play an important role in the mechanisms of neuronal cell damage under ischemia as well as in neurodegenerative disorders (Takahashi et al., 2000). Central neurons have multiple types of voltage-dependent potassium channels (Segal et al. 1984), and potassium currents are also especially important for the regulation of neuronal excitability, because they repolarize neurons in response to depolarizing events and help to stabilize the membrane potential below the firing threshold. The transient potassium current $\left(\mathrm{I}_{\mathrm{A}}\right.$, fast activating, fast inactivating, and sensitive to 4-aminopyridine at $3 \mathrm{mM}$ ) is important to determine the spike threshold because it is activated near the resting membrane potential range and affects the latency of first spike. The "classcal" noninactivating delayed rectifier-type potassium current ( $\mathrm{I}_{\mathrm{K}}$, slowly activating, noninactivating, and sensitive to external TEA at 3-25 $\mathrm{mM}$ ), that is responsible for the fast repolarization of the membrane potential after action potentials (APs) in spiking neurons. It helps to determine the spike width and postspike hyperpolarization, and can help shape the maximal spike frequency of neurons (Mitterdorfer and Bean, 2002). However, little is known about the potential hazard of high concentration of manufactured nanoscale $\mathrm{ZnO}$ on the CNS. Moreover, a little knowledge about whether nanoparticle zinc oxide (nano- $\mathrm{ZnO}$ ) have effect on ion channels and neuronal excitability, although zinc $\left(\mathrm{Zn}^{2+}\right)$ functions as a signaling molecule in the nervous system (Beyersmann and Haase, 2001) and regulates several voltage-gated ionic conductances, including $\mathrm{K}^{+}, \mathrm{Na}^{+}$and $\mathrm{Ca}^{2+}$ conductances (Mathie et al., 2006). Therefore, it is necessary to examine the possible effects on ion channels, when neurons exposed to a commercially available nano- $\mathrm{ZnO}$. In the present study, whole cell patch-clamp technique, a more direct experimental approach was used to determine the effects of nano- $\mathrm{ZnO}$ on voltage-gated ionic currents and changes in action potential waveforms in acutely isolated rat hippocampal CA3 neurons, and attempt to investigate the possible mechanisms of nano- $\mathrm{ZnO}$ on central nervous system.

\section{Materials and methods}

\subsection{Cell preparation and solutions.}

Wistar rats (postnatal day 10-14) were obtained from Experimental Animal Center, 
Chinese Academy of Medical Sciences. The experiments were conducted in accordance with the guidelines of the Medical Experimental Animal Administrative Committee of the Nation, and all efforts were made to minimize the number of animal used and their suffering. Single rat hippocampal CA3 pyramidal neurons were acutely isolated by enzymatic digestion and mechanical dispersion according to the method (Zou et al., 2000) with the following modifications. Briefly, Wistar rats were anesthetized and decapitated, then brains were quickly removed and placed in ice-cold, oxygenated dissociation $\left(95 \% \mathrm{O}_{2}-5 \% \mathrm{CO}_{2}\right)$ in artificial cerebrospinal solution fluids (aCSF) containing (in $\mathrm{mM}$ ): $\mathrm{NaCl} 126, \mathrm{KCl} 3.5, \mathrm{NaH}_{2} \mathrm{PO}_{4} 1.5, \mathrm{MgSO}_{4} 2, \mathrm{CaCl}_{2} 2$, $\mathrm{NaHCO}_{3} 25$, Glucose 10 (buffered to $\mathrm{pH} 7.4$ with $\mathrm{NaOH}$ ) within 1 min. Hippocampi were dissected and cut into approximately $400 \mu \mathrm{m}$-thick transverse slices. The regions of the CA3 neurons were isolated and incubated for $50 \mathrm{~min}$ at $32^{\circ} \mathrm{C}$ in aCSF, bubbled with $95 \% \mathrm{O}_{2}-5 \% \mathrm{CO}_{2}$; and successively transferred into aCSF containing $0.5 \mathrm{mg} / \mathrm{ml}$ protease for $15 \mathrm{~min}$ at $32^{\circ} \mathrm{C}$, bubbled with $95 \% \mathrm{O}_{2}-5 \% \mathrm{CO}_{2}$. After digestion the tissue pieces were rinsed 3 times with aCSF to end the enzyme's function. The CA3 regions were dissected and triturated to release single cells through a series of fire-polished Pasteur pipette with tip diameter from 150 to $500 \mu \mathrm{m}$. The cell suspension was transferred into a $35 \mathrm{~mm}$ culture dish filled with $2 \mathrm{ml}$ extracellular solution, containing (in $\mathrm{mM}$ ): $\mathrm{NaCl} 130, \mathrm{KCl} 5, \mathrm{MgCl}_{2} 1, \mathrm{CaCl}_{2}$ 2, Glucose 10, Hepes 10, and $\mathrm{pH}$ 7.4. Twenty minutes later, the cells were attached to the bottom of the culture dish and were ready for experiments. Pyramidal neurons were easily identified morphologically with bright pyramidal-shaped soma and two or three short branched dendrites and a long axon. These neurons remained viable for electrophysiological studies up to 4-5 h.

The standard pipette solution for current-clamp experiments was (in $\mathrm{mM}$ ): $\mathrm{KCl} 130$, $\mathrm{CaCl}_{2} 1, \mathrm{MgCl}_{2}$ 2, EGTA 10, Hepes 10, Mg-ATP 2, buffered to $\mathrm{pH} 7.2$ with $\mathrm{KOH}$.

The standard pipette solution for recording sodium current containing (in $\mathrm{mM}$ ): $\mathrm{CsCl} 140, \mathrm{MgCl}_{2}$ 2, HEPES 10, EGTA 10, TEA-Cl 10, Mg-ATP 2, buffered to $\mathrm{pH}$ 7.2 with $\mathrm{CsOH}$.

The standard pipette solution for recording voltage-dependent potassium current containing (in mM): $\mathrm{KCl} \mathrm{65,} \mathrm{KF} 80, \mathrm{KOH} 5$, Hepes 10, EGTA 10, Mg-ATP 2, buffered to $\mathrm{pH} 7.2$ with $\mathrm{KOH}$. Tetrodotoxin (TTX, $0.001 \mathrm{mM}$ ) and cadmium chloride $(\mathrm{CdCl}, 0.2 \mathrm{mM})$ were added into the extracellular solution to block $\mathrm{Na}^{+}$and $\mathrm{Ca}^{2+}$ channels (Chi and $\mathrm{Xu}$. 2000). Two types of voltage-dependent potassium channels known as $\mathrm{I}_{\mathrm{A}}$ (fast activating, fast inactivating, and sensitive to 4-aminopyridine at 3 $\mathrm{mM}$ ), and $\mathrm{I}_{\mathrm{K}}$ (slowly activating, noninactivating, and sensitive to external tetraethylammonium chloride at 3-25 mM) (Mitterdorfer and Bean, 2002) were distinguished respectively in presence of tetraethylammonium chloride (TEA-Cl, 25 $\mathrm{mM}$ ) and 4-aminopyridine (4-AP, $3 \mathrm{mM}$ )(Segal et al., 1984).

\subsection{Whole cell recordings}

Whole cell currents were recorded with EPC10 patch clamp amplifier (HEKA, Germany). A micropipette puller (PIP5, HEKA, Germany) was used to pull the 
electrodes. The patch electrodes had a tip resistance of 5 8 $\mathrm{M} \Omega$ when filled with pipette solution. After the formation of a giga seal, the pipette resistance and capacitance were compensated electronically. After the rupture of the membrane and the establishment of a whole cell voltage-clamp configuration, compensation (80\%) for series resistance was routinely used. Data were low-pass filtered at $2.9 \mathrm{kHz}$, digitized at $10 \mathrm{kHz}$ (four pole Bessel filter) and stored in an Intel-based computer using Pulse 8.74 software (HEKA, Germany). All experiments were performed at room temperature $\left(21-24^{\circ} \mathrm{C}\right)$.

\subsection{Nanoparticle $\mathrm{ZnO}$ and solutions}

Zinc oxide is nearly insoluble in water but soluble in acids and bases. It occurs as white powder known as zinc white which occurs in nature as the mineral zincite. Crystalline $\mathrm{ZnO}$ exhibits the piezoelectric effect and is thermochromic, changing from white to yellow when heated. Zinc oxide decomposes into zinc vapor and oxygen only at around $1975^{\circ} \mathrm{C}$, reflecting its considerable stability. Heating with carbon converts the oxide into zinc: $\mathrm{ZnO}+\mathrm{C} \rightarrow \mathrm{Zn}+\mathrm{CO}$. In this research, the nano- $\mathrm{ZnO}$ was analyzed and provided by IntriciQ Materials, Farnborough, Hants GU14 OLX, UK. The Transmission Electron Microscopy (TEM, Tecnai G2 20 S-TWIN, FEI, USA) images showed that $\mathrm{ZnO}$ nanoparticles were with the sizes of $20-80 \mathrm{~nm}, 2$ or 3 types of crystal shapes(as shown in Fig.1), which might provide different functionalities such as photocatalytics and photovoltaic capabilities.

Stock solution $\left(10^{-2} \mathrm{~g} / \mathrm{ml}\right)$ of nano-ZnO was prepared in Milli-Q water and dispersed by ultrasonic vibration for $20 \mathrm{~min}$. Nano- $\mathrm{ZnO}$ suspension $\left(10^{-4} \mathrm{~g} / \mathrm{ml}\right)$ in artificial cerebrospinal fluid (ACSF) were characterized by Dynamic Light Scattering(DLS) using a ZetaPALS+ BI-90Plus (Brookhaven Instruments Corp. USA) at a wavelength of $659 \mathrm{~nm}$. The scattering angle was fixed at $90^{\circ}$. The particle size distribution had a wide range from $65 \mathrm{~nm}$ to $1534 \mathrm{~nm}$ due to the aggregation, and the hydrodynamic diameter was $371 \mathrm{~nm}$. Its suspension was stirred on vortex agitator before every use.

\subsection{Drug application and data analysis}

According to our experiment in nanoparticle $\mathrm{CuO}(\mathrm{Xu}$ et al., 2008), and the preliminary experiment showed that $10^{-5} \mathrm{~g} / \mathrm{ml}$ and $10^{-6} \mathrm{~g} / \mathrm{ml}$ nano- $\mathrm{ZnO}$ had no significant effects on whole cell current in acutely isolated rat hippocampal CA3 pyramidal neurons $(\mathrm{p}>0.05)$, however, $10^{-4} \mathrm{~g} / \mathrm{ml}$ nano- $\mathrm{ZnO}$ could have obvious effects on whole cell current $(\mathrm{p}<0.05)$. Therefore, final concentration of $10^{-4} \mathrm{~g} / \mathrm{ml}$ nano- $\mathrm{ZnO}$ suspension was used to examine the effects on the properties of voltage-dependent sodium, potassium currents and evoked action potentials in acutely isolated rat hippocampal CA3 pyramidal neurons.

Final concentration of $10^{-4} \mathrm{~g} / \mathrm{ml}$ nano- $\mathrm{ZnO}$ suspension was added into extracellular solution once currents were stable (about 3 5 min). The nano- $\mathrm{ZnO}$ deposited around the recording cell and played a direct role on cell. Drug actions were measured only after steady-state conditions reached, which were judged by the amplitudes and time courses of currents remaining constant. 
Tetrodotoxin (TTX) was purchased from the Research Institute of the Aquatic Products of Hebei (China). 4-aminopyridine (4-AP), tetraethylammonium chloride (TEA-Cl), $\mathrm{CsOH}, \mathrm{CdCl}$, EGTA, Hepes, $\mathrm{Mg}$-ATP and Protease were purchased from Sigma(USA), and other reagents were of AR grade.

All data were analyzed and fitted by using Igor Pro 5.04 (Wavemetrics, Lake Oswego, OR, USA) and Origin 7.5 (Microcal Software, USA) softwares. All values were represented as mean \pm SEM and statistical comparisons were made using the Student's paired t-test and one-way analysis of variance (ANOVA). A probability value less than 0.05 was considered to be statistically significant.

\section{Results}

\subsection{Effects of nano- $\mathrm{ZnO}$ on $\mathrm{I}_{\mathrm{Na}}$}

TTX-sensitive sodium current carried the largest inward current. For recording sodium current, $\mathrm{CdCl}(0.2 \mathrm{mM})$ was added into the extracellular solution to suppress $\mathrm{Ca}^{2+}$ currents. In whole cell patch-clamp recording, cells were held at a holding potential of $-100 \mathrm{mV}$, and $20 \mathrm{~ms}$ depolarizing potentials from -100 to $+60 \mathrm{mV}$ at $10 \mathrm{mV}$ steps activated inward currents which were completely and reversibly blocked by bath application of $0.001 \mathrm{mM}$ TTX. Therefore, these inward currents were attributed to sodium currents $\mathrm{I}_{\mathrm{Na}}$.

Final concentration of $10^{-4} \mathrm{~g} / \mathrm{ml}$ nano- $\mathrm{ZnO}$ was applied in the extracellular solution once sodium currents were stable (about 3 5 min). The peak amplitudes of $\mathrm{I}_{\mathrm{Na}}$ were increased at more different membrane potentials as compared with the control, as shown in Fig.2A. The current-voltage curve of $\mathrm{I}_{\mathrm{Na}}$ was decreased, and the peak amplitudes of $\mathrm{I}_{\mathrm{Na}}$ were increased obviously from -50 to $+20 \mathrm{mV}(\mathrm{n}=11, \mathrm{P}<0.05 \mathrm{vs}$. control), as shown in Fig.2B.

\subsubsection{Effects of nano- $\mathrm{ZnO}$ on activation kinetics of $\mathrm{I}_{\mathrm{Na}}$}

The steady-state activation curves for $\mathrm{I}_{\mathrm{Na}}$ under control conditions and after exposure to nano- $\mathrm{ZnO}$ were shown in Fig.2C. The curves were fitted well with the Boltzmann equation $G / G_{\max }=1 /\left\{1+\exp \left[\left(V_{m}-V_{h}\right) / k\right]\right\}$. First, the current amplitudes evoked by the step pulses were converted into conductance by using the equation $\mathrm{G}=$ $\mathrm{I} /\left(\mathrm{V}_{\mathrm{m}}-\mathrm{V}_{\mathrm{r}}\right)$, where $\mathrm{G}$ is the conductance, $\mathrm{I}$ is the current, $\mathrm{V}_{\mathrm{m}}$ is the membrane potential, and $\mathrm{V}_{\mathrm{r}}$ is the reversal potential. In Boltzmann equation, $\mathrm{V}_{\mathrm{h}}$ is the membrane potential at half-activation, and $\mathrm{k}$ is slope factor.

The values of $\mathrm{V}_{\mathrm{h}}$ for activation of $\mathrm{I}_{\mathrm{Na}}$ in control and nano- $\mathrm{ZnO}$ were $-55.75 \pm 2.59$ $\mathrm{mV}$ and $-59.60 \pm 2.74 \mathrm{mV}(\mathrm{n}=11, \mathrm{P}>0.05)$, with a slope factor $\mathrm{k}$ of $5.57 \pm 2.25 \mathrm{mV}$ and $6.09 \pm 2.54 \mathrm{mV}(\mathrm{n}=11, \mathrm{P}>0.05)$, respectively. There was no statistical difference between the values of $\mathrm{V}_{\mathrm{h}}$ in control and nano- $\mathrm{ZnO}$, and the slope factor remained unchanged.

\subsubsection{Effects of nano- $\mathrm{ZnO}$ on inactivation kinetics of $\mathrm{I}_{\mathrm{Na}}$}


The steady-state inactivation of $\mathrm{I}_{\mathrm{Na}}$ was determined by a double-pulse protocol: applying $50 \mathrm{~ms}$ conditioning prepulses to potentials between -100 and $-10 \mathrm{mV}$ in $5 \mathrm{mV}$ increments, followed by a $20 \mathrm{~ms}$ depolarizing pulse to $-10 \mathrm{mV}$, and holding potential at $-100 \mathrm{mV}$ (as shown in Fig.3A). Peak amplitudes for $\mathrm{I}_{\mathrm{Na}}$ currents were normalized and plotted vs prepulse potentials. The inactivation curves were well fitted with the Boltzmann equation: $\mathrm{I} / \mathrm{I}_{\max }=1 /\left\{1+\exp \left[\left(\mathrm{V}_{\mathrm{m}}-\mathrm{V}_{\mathrm{h}}\right) / \mathrm{k}\right]\right\}$, where $\mathrm{I}_{\max }$ is the maximal current, $\mathrm{V}_{\mathrm{h}}$ is the membrane potential at half-inactivation, and $\mathrm{k}$ is slope factor(as shown in Fig.3B). The values of $\mathrm{V}_{\mathrm{h}}$ for inactivation of $\mathrm{I}_{\mathrm{Na}}$ before and after addition of nanoparticle $\mathrm{ZnO}$ are $-52.54 \pm 0.43 \mathrm{mV}$ and $-54.67 \pm 0.39 \mathrm{mV}(\mathrm{n}=8, \mathrm{P}<0.01)$, with a slope factor $k$ of $9.32 \pm 0.42 \mathrm{mV}$ and $8.72 \pm 0.38 \mathrm{mV}(\mathrm{n}=8, \mathrm{P}>0.05)$, respectively.

\subsubsection{Effects of nano- $\mathrm{ZnO}$ on recovery from inactivation of $\mathrm{I}_{\mathrm{Na}}$}

Once the $\mathrm{I}_{\mathrm{Na}}$ is inactivated following membrane depolarization, a sufficient amount of hyperpolarizing time must elapse before the channel can recover and be fully activated again. In order to determine the kinetics of recovery from the inactivated channel state, cells were held at $-90 \mathrm{mV}$, a $50 \mathrm{~ms}$ conditioning depolarizing pulse of $-40 \mathrm{mV}$ was applied to inactivate the sodium channels fully, and then a $50 \mathrm{~ms}$ test pulse of $-40 \mathrm{mV}$ was applied after a series of $-90 \mathrm{mV}$ intervals varying from 2 to $36 \mathrm{~ms}$ (in 2 ms increments, as shown in Fig.4A). The peak value of $\mathrm{I}_{\mathrm{Na}}$ evoked by the conditioning pulse was designated as $I_{1}$, while the peak value of $I_{\mathrm{Na}}$ evoked by the test pulse was designated as $\mathrm{I}_{2}$. The ratio of $\mathrm{I}_{2}$ to $\mathrm{I}_{1}$ represents the recovery of $\mathrm{I}_{\mathrm{Na}}$ from inactivation. The plot of $\mathrm{I}_{2} / \mathrm{I}_{1}$ vs the duration of the $-90 \mathrm{mV}$ intervals was well fitted with a monoexponential function: $\mathrm{I} / \mathrm{I}_{\max }=\mathrm{A}+\mathrm{B} \exp (-\mathrm{t} / \tau)$, where $\mathrm{t}$ is the recovery interval of the conditioning prepulse and $\tau$ is the time constant for the recovery from inactivation of $\mathrm{I}_{\mathrm{Na}}$ (as shown in Fig.4B). The time constants $(\tau)$, which described the recovery time course, before and after addition of nano- $\mathrm{ZnO}$ were $5.40 \pm 0.19 \mathrm{~ms}$ and $3.95 \pm 0.15 \mathrm{~ms}(\mathrm{n}=8, \mathrm{P}<0.01)$, respectively. The results indicated $10^{-4} \mathrm{~g} / \mathrm{ml}$ nano- $\mathrm{ZnO}$ accelerated the recovery of $\mathrm{I}_{\mathrm{Na}}$ from inactivation.

\subsection{Effects of nano- $\mathrm{ZnO}$ on voltage-dependent potassium currents $\left(\mathrm{I}_{\mathrm{A}}\right.$ and $\left.\mathrm{I}_{\mathrm{K}}\right)$}

In whole cell patch-clamp recording, $\operatorname{TTX}(0.001 \mathrm{mM})$ and $\mathrm{CdCl}(0.2 \mathrm{mM})$ were added into the extracellular solution to block $\mathrm{Na}^{+}$and $\mathrm{Ca}^{2+}$ channels. In order to record transient outward potassium current $\left(\mathrm{I}_{\mathrm{A}}\right)$, TEA-Cl $(25 \mathrm{mM})$ was also used to inhibit delayed rectifier potassium current $\left(\mathrm{I}_{\mathrm{K}}\right)$. And the holding potential was $-70 \mathrm{mV}$, using an 80ms constant depolarizing pulse from a command potential of -50 to +90 $\mathrm{mV}$ in increments of $10 \mathrm{mV} . \mathrm{I}_{\mathrm{K}}$ was obtained using a $160 \mathrm{~ms}$ constant depolarizing pulse by a similar pulse protocol in present of 4-AP $(3 \mathrm{mM})$.

After 5 min's stable current recordings, final concentration of $10^{-4} \mathrm{~g} / \mathrm{ml}$ nano- $\mathrm{ZnO}$ was applied in the extracellular solution. The amplitudes of $I_{A}$ and $I_{K}$ were both increased at more different membrane potentials (as shown in Fig.5A and Fig.5B), the current-voltage curve of $I_{A}$ was increased but there was no statistically significant ( $n=6, P>0.05$ vs. control). While the current-voltage curve of $I_{K}$ was significantly increased by nano- $\mathrm{ZnO}$ from +20 to $+90 \mathrm{mV}$ ( $\mathrm{n}=6, \mathrm{P}<0.05$ vs. control, as shown in Fig.5C and Fig.5D). 


\subsubsection{Effects of nano- $\mathrm{ZnO}$ on the activation kinetics of $\mathrm{I}_{\mathrm{A}}$ and $\mathrm{I}_{\mathrm{K}}$}

The steady-state activation curves for $\mathrm{I}_{\mathrm{A}}$ and $\mathrm{I}_{\mathrm{K}}$ under control conditions and after exposure to nano- $\mathrm{ZnO}$ are shown in Fig. 5E and Fig.5F. The curves were fitted well with the Boltzmann equation $\mathrm{G} / \mathrm{G}_{\max }=1 /\left\{1+\exp \left[\left(\mathrm{V}_{\mathrm{m}}-\mathrm{V}_{\mathrm{h}}\right) / \mathrm{k}\right]\right\}$ (as described in Results 3.1.1 ). The values of $\mathrm{V}_{\mathrm{h}}$ for activation of $\mathrm{I}_{\mathrm{A}}$ in control and nano- $\mathrm{ZnO}$ groups were $23.97 \pm 1.33 \mathrm{mV}$ and $29.22 \pm 1.73 \mathrm{mV}(\mathrm{n}=6, \mathrm{P}>0.05)$, with a slope factor $\mathrm{k}$ of 30.85 $\pm 1.85 \mathrm{mV}$ and $34.45 \pm 2.42 \mathrm{mV}(\mathrm{n}=6, \mathrm{P}>0.05)$, respectively; and $\mathrm{V}_{\mathrm{h}}$ for activation of $\mathrm{I}_{\mathrm{k}}$ in control and nano- $\mathrm{ZnO}$ groups were $33.09 \pm 1.06 \mathrm{mV}$ and $32.07 \pm 0.87 \mathrm{mV}(\mathrm{n}$ $=6, \mathrm{P}>0.05)$, with a slope factor $\mathrm{k}$ of $29.96 \pm 1.25 \mathrm{mV}$ and $27.34 \pm 1.01 \mathrm{mV}(\mathrm{n}=6$, $\mathrm{P}>0.05$ ), respectively. Thus, there were no significant effects of nano- $\mathrm{ZnO}$ on the activation kinetics of $\mathrm{I}_{\mathrm{A}}$ and $\mathrm{I}_{\mathrm{K}}$.

\subsubsection{Effects of nano- $\mathrm{ZnO}$ on the inactivation kinetics of $\mathrm{I}_{\mathrm{A}}$}

The steady state inactivation of $\mathrm{I}_{\mathrm{A}}$ was determined by applying $80 \mathrm{~ms}$ conditioning prepulses to potentials between -120 and $+10 \mathrm{mV}$ in $10 \mathrm{mV}$ increments, followed by a $100 \mathrm{~ms}$ depolarizing pulse to $+50 \mathrm{mV}$, and holding potential at $-80 \mathrm{mV}$ (as shown in Fig.6A). Peak amplitudes for $\mathrm{I}_{\mathrm{A}}$ currents were normalized and plotted vs prepulse potentials. The inactivation curves were well fitted with the Boltzmann equation: $\mathrm{I} / \mathrm{I}_{\max }=1 /\left\{1+\exp \left[\left(\mathrm{V}_{\mathrm{m}}-\mathrm{V}_{\mathrm{h}}\right) / \mathrm{k}\right]\right\}$, where $\mathrm{I}_{\max }$ is the maximal current, $\mathrm{V}_{\mathrm{h}}$ is the membrane potential at half-inactivation, and $\mathrm{k}$ is slope factor. The values of $\mathrm{V}_{\mathrm{h}}$ for inactivation of $\mathrm{I}_{\mathrm{A}}$ before and after addition of nano- $\mathrm{ZnO}$ were $-69.09 \pm 0.56 \mathrm{mV}$ and $-68.79 \pm 0.65 \mathrm{mV}$ $(\mathrm{n}=6, \mathrm{P}>0.05)$, with a slope factor $\mathrm{k}$ of $9.59 \pm 0.49 \mathrm{mV}$ and $10.85 \pm 0.57 \mathrm{mV}(\mathrm{n}=6$, $\mathrm{P}>0.05)$, respectively. Thus, there were no significant effects of nano- $\mathrm{ZnO}$ on the inactivation of $\mathrm{I}_{\mathrm{A}}$, as shown in Fig.6B.

\subsubsection{Effects of nano- $\mathrm{ZnO}$ on the recovery from inactivation of $\mathrm{I}_{\mathrm{A}}$}

In order to determine the kinetics of recovery from the inactivated channel state, cells were held at $-70 \mathrm{mV}$, and an $80 \mathrm{~ms}$ conditioning depolarizing pulse of $+50 \mathrm{mV}$ was applied to inactivate the transient outward potassium channels fully, and then an $80 \mathrm{~ms}$ test pulse of $+50 \mathrm{mV}$ was applied after a series of $-80 \mathrm{mV}$ intervals varying from 10 to $260 \mathrm{~ms}$ (in $10 \mathrm{~ms}$ increments, as shown in Fig.7A). The peak value of $\mathrm{I}_{\mathrm{A}}$ evoked by the conditioning pulse was designated as $I_{1}$, while the peak value of the $I_{A}$ evoked by the test pulse was designated as $I_{2}$. The ratio of $I_{2}$ to $I_{1}$ represents the recovery of $I_{A}$ from inactivation. The plot of $I_{2} / I_{1}$ vs the duration of the $-80 \mathrm{mV}$ intervals was well fitted with a monoexponential function $\mathrm{I} / \mathrm{I}_{\max }=\mathrm{A}+\mathrm{B} \exp (-\mathrm{t} / \tau)$, where $t$ is the recovery interval of the conditioning prepulse and $\tau$ is the time constant for the recovery from inactivation of $\mathrm{I}_{\mathrm{A}}$. The time constants $(\tau)$, which described the recovery time course, before and after addition nano- $\mathrm{ZnO}$ were $34.67 \pm 2.47 \mathrm{~ms}$ and $31.76 \pm 2.26 \mathrm{~ms}(\mathrm{n}=6, \mathrm{P}>0.05)$, respectively. The nano- $\mathrm{ZnO}$ had no marked effect on the recovery of $\mathrm{I}_{\mathrm{A}}$ from inactivation, as shown in Fig.7B.

\subsection{Effects of nano- $\mathrm{ZnO}$ on action potential}

Action potential properties and the pattern of repetitive firing were examined using whole cell current-clamp recordings. Evoked action potentials were generated from a 
holding potential of $-70 \mathrm{mV}$. Single action potential was elicited by brief depolarizing current pulses ( $5 \mathrm{~ms}, 100 \mathrm{pA})$, and repetitive firing was evoked by a prolonged depolarizing current injection (500 ms, 50 pA). Peak amplitude, overshoot, spike half-width of single action potential and firing rate of repetitive firing were measured before and after drug applications (as shown in Table 1). Peak amplitude and overshoot of the evoked single action potential were increased and half-width was diminished in the present of the $10^{-4} \mathrm{~g} / \mathrm{ml}$ nano- $\mathrm{ZnO}$ solution, and the firing rate of repetitive firing was also increased $(n=6, p<0.05)$ ( as shown in Fig.8 and Fig.9).

\section{Discussion}

Recent experimental studies indicated that surface modified nanoparticle can cross most strong biological barriers such as blood-brain barrier (Lockman et al., 2003, 2004) and inhaled ultrafine particles via the olfactory neuronal pathway enter into the CNS of exposed animals (Oberdorster et al., 2004; Elder et al., 2006). It has been demonstrated that nanosize titanium dioxide stimulates reactive oxygen species in brain microglia and damages neurons in vitro (Long et al., 2007). More studies about nano- $\mathrm{ZnO}$ showed that the antibacterial activity or adverse effects were partly due to the result of the generation of reactive oxygen species (ROS)(Yamamoto et al., 2004; Ghule et al., 2006; Tam et al., 2008) or causing membrane damage through the direct nanoparticle-cell membrane wall interaction or generation of ROS (Brayner et al., 2006; Zhang et al., 2007; Reddy et al., 2007; Heinlaan et al., 2008) or release of zinc ions in the $\mathrm{ZnO}$ particle suspensions (Brunner et al., 2006; Franklin et al., 2007; Zhu et al., 2008; Heinlaan et al., 2008). Studies in mammals suggested that nanoscale $\mathrm{ZnO}$ oral exposure could cause the increase in blood viscosity and the pathological lesions in the gastric, liver, renal, pancreas and spleen (Wang et al., 2008). However, the potential hazard of high concentration of manufactured nanoscale $\mathrm{ZnO}$ on the CNS is known little. Moreover, it has little knowledge about whether nano-ZnO has effect on ion channels and neuronal excitability.

This is the first study to evaluate the acute effects of nano- $\mathrm{ZnO}$ on the properties of voltage-dependent sodium, potassium currents and evoked action potentials by using the whole-cell patch clamp technique in acutely isolated rat hippocampal CA3 pyramidal neurons. The results showed that (1) In the present of final concentration of $10^{-4} \mathrm{~g} / \mathrm{ml}$ nano- $\mathrm{ZnO}$, the peak amplitudes of $\mathrm{I}_{\mathrm{Na}}$ were increased considerably from -50 to $+20 \mathrm{mV}(\mathrm{p}<0.05)$. The kinetic analysis demonstrated that the inactivation and the recovery from inactivation of $\mathrm{I}_{\mathrm{Na}}$ were also promoted by the nano- $\mathrm{ZnO}$ solution $(\mathrm{p}<0.01)$. However, the steady-state activation curve of $\mathrm{I}_{\mathrm{Na}}$ was not altered. (2) The amplitudes of $\mathrm{I}_{\mathrm{A}}$ were increased by the nano- $\mathrm{ZnO}$ solution, while amplitudes of $\mathrm{I}_{\mathrm{K}}$ was significantly increased from +20 to $+90 \mathrm{mV}(\mathrm{p}<0.05)$. However, the kinetic analysis demonstrated that the steady-state activation curve of $\mathrm{I}_{\mathrm{A}}$ and $\mathrm{I}_{\mathrm{K}}$ remained unchanged, and nano- $\mathrm{ZnO}$ had no significant effect on the inactivation and the recovery from inactivation of $\mathrm{I}_{\mathrm{A}}$. (3) Peak amplitude and overshoot of the evoked single action potential were increased and half-width was diminished in the present of 
nano- $\mathrm{ZnO}(\mathrm{p}<0.05)$. Simultaneously, firing rate of repetitive firing evoked by a prolonged depolarizing current injection was increased $(\mathrm{p}<0.05)$.

\section{The effect of nano- $\mathrm{ZnO}$ on voltage-gated sodium channels in acutely isolated rat hippocampal CA3 pyramidal neurons}

Voltage-gated sodium channels are responsible for the largest inward current during the depolarization phase of action potential in excitable cells. $\mathrm{Na}^{+}$channels open and inactivate in response to a depolarization of the resting membrane potential. When these channels open, an influx of $\mathrm{Na}^{+}$occurs, depolarizing the membrane potential, and generating the upstroke phase of the action potential. Inactivation of $\mathrm{Na}^{+}$channels stops $\mathrm{Na}^{+}$influx, preventing a permanent depolarization of the resting membrane potential. Recovery from inactivation allows the cell membrane to regain its resting excitable properties. The channels of $\mathrm{Na}^{+}$play important roles both in vital physiological functions and several pathological processes of the CNS. Results from in vitro and in vivo studies support the idea that $\mathrm{Na}^{+}$channels are involved in Alzheimer's disease (AD) and injury in CNS neurons, and have been proposed as a potential target for drug treatment as well. It has also been widely accepted that an increase $\mathrm{Na}^{+}$influx through voltage-gated $\mathrm{Na}^{+}$channels upon depolarization exacerbates neuronal cell damage (Lynch et al., 1995; Stys, 1998). Growing evidence also suggests that the reduction in voltage-gated $\mathrm{Na}^{+}$channel activity improves cell survival and reduces hypoxia-induced injury (Lynch et al., 1995; Taylor and Meldrum, 1995; Martínez-Sánchez et al., 2004). Meanwhile activation of $\mathrm{Na}^{+}$channels by veratridine has been used as a depolarization-induced neuronal injury model eliciting $\mathrm{Ca}^{2+}$-dependent neuronal damage (Takahashi et al., 1999, 2000; Takano et al., 2003; Akasofu et al., 2008). Epilepsy, chronic pain, neurodegenerative diseases, and spasticity are all characterized by an over-excited state of specific groups of central neurons that is accompanied by an abnormally increased activity of sodium channels. Therefore, an efficient strategy of controlling such diseases is to use blockers that preferentially act on these over-excited cells. Various blockers of the $\mathrm{Na}^{+}$channel, including phenytoin, or lamotrigine, leave normal physiological functions relatively intact, resulting in a favorable therapeutic window (Tarnawa et al., 2007). Our experimental results suggested that the peak amplitudes of $\mathrm{I}_{\mathrm{Na}}$ were increased obviously from -50 to $+20 \mathrm{mV}$ ( $\mathrm{n}=11, \mathrm{P}<0.05 \mathrm{vs}$. control) in the present of $10^{-4} \mathrm{~g} / \mathrm{ml}$ nano- $\mathrm{ZnO}$, but the steady-state activation curve of $\mathrm{I}_{\mathrm{Na}}$ was not altered. The kinetic analysis demonstrated that the inactivation and the recovery from inactivation of $\mathrm{I}_{\mathrm{Na}}$ were also promoted by the nano- $\mathrm{ZnO}$ solution $(\mathrm{p}<0.01)$, which suggested that the nano- $\mathrm{ZnO}$ may increase the neuronal excitability. Therefore, the results support the above point that activation of $\mathrm{Na}^{+}$channels by nano- $\mathrm{ZnO}$ solution could lead to depolarization-induced neuronal injury. Additionally, the increase of peak amplitudes of $\mathrm{I}_{\mathrm{Na}}$ by nano- $\mathrm{ZnO}$ solution could contribute to increase $\mathrm{Na}^{+}$influx and add to the intracellular $\mathrm{Na}^{+}$load. The consequent increases in intracellular $\mathrm{Na}^{+}$concentration may contribute to an increase intracellular $\mathrm{Ca}^{2+}$ due to activation of voltage-gated $\mathrm{Ca}^{2+}$ channels and a reversed operation of the $\mathrm{Na}^{+}-\mathrm{Ca}^{2+}$ exchanger (Xiao et al., 2002). An increase in intracellular $\mathrm{Ca}^{2+}$ is generally believed to be a trigger for excitotoxicity 
of necrotic cell death (Choi, 1988). Furthermore, the increase in intracellular $\mathrm{Na}^{+}$ favors the passive influx of chloride $\left(\mathrm{Cl}^{-}\right)$and water. This causes neuronal swelling and other signs of acute neuronal injury, such as the formation of blebs in the membrane (Jiang et al., 1991; Friedman and Haddad, 1994).

\section{The effect of nano-ZnO on voltage-gated potassium channels in acutely isolated rat hippocampal $\mathrm{CA3}$ pyramidal neurons}

In the nervous system, voltage-gated $\mathrm{K}^{+}$currents determine a large number of neuronal properties, such as resting membrane potential, action potential(AP) waveform, and fire frequency, and are known to play important roles in all cell types underlying both normal and pathophysiological functions. $\mathrm{I}_{\mathrm{A}}$ and $\mathrm{I}_{\mathrm{K}}$ are the two main neuronal voltage-gated $\mathrm{K}^{+}$current; they contribute to AP repolarization and repetitive firing. In the present study, the current-voltage curve of $\mathrm{I}_{\mathrm{K}}$ was significantly increased from +20 to $+90 \mathrm{mV}$ ( $\mathrm{n}=6, \mathrm{P}<0.05$ vs. control). However, the nano- $\mathrm{ZnO}$ solution didn't shift the steady-state activation curve of $\mathrm{I}_{\mathrm{A}}$ and $\mathrm{I}_{\mathrm{K}}$, and neither had a significant effect on the inactivation and the recovery from inactivation of $\mathrm{I}_{\mathrm{A}}$. The results suggest that activation of $\mathrm{K}^{+}$currents by the nano-ZnO solution could be preferential for $\mathrm{I}_{\mathrm{k}}$, and cause the increase of $\mathrm{K}^{+}$efflux and the loss of cytoplasmic $\mathrm{K}^{+}$. In addition, $\mathrm{I}_{\mathrm{K}}$ is responsible for the fast repolarization of the membrane potential after action potentials in spiking neurons, and helps to determine the spike width and postspike hyperpolarization, and can help shape the maximal spike frequency of neurons (Mitterdorfer and Bean, 2002). Therefore, the activation of $I_{k}$ may reduce the spike half-width and increase the spike frequency by rapid $\mathrm{K}^{+}$efflux, and further increase the excitability of neurons. Emerging evidence supports the idea that changes in ionic concentrations, primarily $\mathrm{K}^{+}$, play a pivotal role in the activation and progression of apoptosis (Bortner et al., 1997; Bortner and Cidlowski, 1999; Hughes and Cidlowski, 1999; Montague et al., 1999; Vu et al., 2001). $\mathrm{K}^{+}$is the predominant cation in the cytosol. Maintenance of a high $\left[\mathrm{K}^{+}\right]$in the cytoplasm $(140-150 \mathrm{mM})$ is essential for governing cell excitability, setting resting $\mathrm{E}_{\mathrm{m}}$, regulating apoptotic enzyme activity, and controlling cell volume (Remillard and Yuan, 2004). Cytoplasmic $\mathrm{K}^{+}$ concentration is mainly regulated by the activity of $\mathrm{Na}^{+}-\mathrm{K}^{+}$-ATPase and various $\mathrm{K}^{+}$ channels in the plasma membrane. The loss of cytoplasmic $\mathrm{K}^{+}$due to increased $\mathrm{K}^{+}$ efflux through $\mathrm{K}^{+}$channels, perhaps in particular via $\mathrm{I}_{\mathrm{K}}$, results in cell shrinkage, a major characteristic of apoptosis, and caspase activation, a triggering process in apoptosis (Yu et al., 1997,1999; Krick et al., 2001; Remillard and Yuan, 2004). Therefore, inhibiting $\mathrm{K}^{+}$efflux by reducing the $\mathrm{K}^{+}$electrochemical gradient with high extracellular $\mathrm{K}^{+}$concentrations or pharmacological blockade of $\mathrm{K}^{+}$channels by TEA significantly attenuated the apoptosis. (Bortner et al., 1997; Yu et al., 1999; Thompson et al., 2001). It has also been shown that cytoplasmic $\mathrm{K}^{+}$at normal concentration $(\sim 140 \mathrm{mM})$ inhibits some morphological, biochemical and molecular hallmarks of apoptosis such as cell shrinkage, DNA fragmentation and caspase-3-like protease activation (Bortner et al., 1997; Thompson et al., 2001). Based on the above investigations, we speculated that the nanoparticle $\mathrm{ZnO}$ could involve in the neuronal apoptosis caused by the loss of cytoplasmic $\mathrm{K}^{+}$due to increased $\mathrm{K}^{+}$efflux through 
delayed rectifier potassium channels.

Additionally, there is still compelling evidence indicating an early increase in intracellular $\mathrm{Na}^{+}$followed by a decrease in both intracellular $\mathrm{K}^{+}$and $\mathrm{Na}^{+}$suggesting a regulatory role for these cations during both the initial signaling, and the execution phase of apoptosis (Fernandez-Segura et al., 1999; Bortner and Cidlowski, 2003; Arrebola et al., 2005). The studies point to a role for intracellular sodium increase not only in controlling cell size changes but also in controlling the initial signaling of the cell death cascade (Panayiotidis et al., 2006). Our experimental results showed that the enhancement of $\mathrm{Na}^{+}$influx via activating voltage-gated $\mathrm{Na}^{+}$channels and $\mathrm{K}^{+}$ efflux through delayed rectifier potassium channels by nano- $\mathrm{ZnO}$ would lead to the increase and the loss in intracellular $\mathrm{Na}^{+}$and $\mathrm{K}^{+}$respectively, which are associated with neuronal apoptosis.

\section{The influence of nano-ZnO on evoked action potential in acutely isolated rat hippocampal CA3 pyramidal neurons}

The channel blockers were usually added into the intracellular or extracellular solution to suppress other channel currents in whole cell patch clamp recording when the effects of nano- $\mathrm{ZnO}$ on kinds of ion channels in hippocampal CA3 pyramidal neurons were detected. Action potentials are a fundamental property of excitable cells in the mammalian central nervous system. Many channel types present in a particular neuron work together to determine its firing properties. Excitability may also reflect changes in the properties of voltage-gated membrane channels. So action potential properties and the pattern of repetitive firing were examined using whole cell current-clamp recordings for further detecting the effects of nano-ZnO. The results suggested peak amplitude and overshoot of the evoked single action potential were increased and half-width was diminished in the present of nano- $\mathrm{ZnO}(\mathrm{p}<0.05)$. Simultaneously, firing rate of repetitive firing evoked by a prolonged depolarizing current injection was increased $(p<0.05)$. Therefore, the results confirmed that the increase of the neuronal excitability resulted from the enhancement of current amplitudes of $\mathrm{I}_{\mathrm{Na}}$ and $\mathrm{I}_{\mathrm{K}}$ by the nano- $\mathrm{ZnO}$ solution. Although there are multiple types of potassium channels involved in the repolarization of the action potential and together to determine its firing properties, the neuronal excitability, as a whole, was increased in the present of the nano- $\mathrm{ZnO}$ solution. Therefore, the results support the widely accepted idea that the enhancement of $\mathrm{Na}^{+}$influx and the accumulation of intracellular $\mathrm{Na}^{+}$via activating voltage-gated $\mathrm{Na}^{+}$channels would contribute to depolarizing neurons, causing $\mathrm{Ca}^{2+}$ influx, reversed $\mathrm{Na}^{+}-\mathrm{Ca}^{2+}$ exchange, $\mathrm{K}^{+}$efflux, glutamate release, increasing the neuronal excitability, and eventually lead to the injury of CNS (Choi, 1988; Taylor and Meldrum, 1995; Xiao et al., 2002; Martínez-Sánchez et al., 2004).

In CNS, the increase of the neuronal excitability would consume more cell energy. It has been shown that approximately one half or more of total ATP generated in the brain at resting state is consumed by $\mathrm{Na}^{+}-\mathrm{K}^{+}$-ATPase to maintain proper transmembrane ionic gradients (Erecinska and Silver, 1989). Establishing and 
maintaining high $\mathrm{K}^{+}$and low $\mathrm{Na}^{+}$in the cytoplasm are required for normal resting membrane potentials and various cellular activities. The ionic homeostasis maintained by the $\mathrm{Na}^{+}-\mathrm{K}^{+}$-ATPase is also critical for cell growth, differentiation, and cell survival (Yu, 2003). Our results also showed that peak amplitude and overshoot of the first action potential of repetitive firing were increased in the presence of nanoparticle $\mathrm{ZnO}$, however, peak amplitude and overshoot of the subsequent action potentials of repetitive firing were decreased and membrane potential was raised in contrast to control. Based on the idea that cellular energy expenditure does increase linearly with the frequency of action potentials (Kadekaro et al., 1985), and repetitive firing will result in large increases of $\mathrm{Na}^{+}$influx and $\mathrm{K}^{+}$efflux. So it is likely that $\mathrm{Na}^{+}-\mathrm{K}^{+}$-ATPase could not export intracellular redundant $\mathrm{Na}^{+}$and/or import extracellular $\mathrm{K}^{+}$timely, which would result in the accumulation of intracellular $\mathrm{Na}^{+}$ and loss of intracellular $\mathrm{K}^{+}$, and consequently, reducing the $\mathrm{Na}^{+}$and $\mathrm{K}^{+}$ electrochemical gradient, and thereby decrease peak amplitude and overshoot of the subsequent action potentials of repetitive firing. Therefore, we speculated that the decrease of peak amplitude and overshoot of the subsequent action potentials of repetitive firing may due to the dysfunction or deficiency of $\mathrm{Na}^{+}-\mathrm{K}^{+}$-ATPase, which was failure of maintenance of proper transmembrane ionic gradients. On the other hand, it has been shown that during the execution phase of apoptosis an early increase in intracellular $\mathrm{Na}^{+}$, a decrease in intracellular $\mathrm{Cl}^{-}$and $\mathrm{K}^{+}$, and a decrease in $\mathrm{K}^{+} / \mathrm{Na}^{+}$ ratio were related with inhibition of the $\mathrm{Na}^{+}-\mathrm{K}^{+}$-ATPase (Arrebola et al., 2005).

While zinc, the second most abundant trace metal (after iron) in mammalian tissues, is an essential element for growth, development, DNA synthesis, immunity, and other important cellular processes. The binding of zinc to L-histidine (His) both in plasma and cerebrospinal fluids seems to be involved in transferring zinc to target sites, which regulate its uptake across the brain barrier systems (Takeda et al., 2002). Even within the brain, $90 \%$ of total brain zinc is bound to zinc metalloproteins, with much of the remaining $10 \%$ found in presynaptic vesicles, either loosely bound or free (and therefore, histochemically reactive) (Takeda, 2001). Free $\mathrm{Zn}^{2+}$ modulates many membrane receptors, transporters and channels (Mathie et al., 2006). Taking into account the release of zinc ions in the $\mathrm{ZnO}$ particle suspensions (Franklin et al., 2007; Zhu et al., 2008), we performed the dissolution tests of different concentration of nano- $\mathrm{ZnO}$ suspensions in artificial cerebrospinal fluid (ACSF, $\mathrm{pH}$ 7.4). Zinc concentration in supernatants of the nanoparticle suspensions after centrifugation (13,000 rpm, for 30min) and filtration (100nm filter) was determined by an inductively coupled plasma optical emission spectrometry (ICP-OES, ICP-9000 $(\mathrm{N}+\mathrm{M})$, Thermo Jarrell-Ash Corp. USA). The concentrations of soluble zinc ions is $0.86 \sim 2.07 \mathrm{mg} / \mathrm{L}\left(13.28 \sim 30.8 \mu \mathrm{M}\right.$ ) in the nano $\mathrm{ZnO}$ suspension(from $10^{-5} \mathrm{~g} / \mathrm{ml}$ to $10^{-3} \mathrm{~g} / \mathrm{ml}$ ). The results of nano- $\mathrm{ZnO}$ (about $26 \mu \mathrm{M} ; 1.69 \mathrm{mg} / \mathrm{L}$ from $10-4 \mathrm{~g} / \mathrm{ml}$ nano- $\mathrm{ZnO}$ ) were not consistent with the modulatory effect of $\mathrm{Zn}^{2+}$ to voltage-gated $\mathrm{K}^{+}$and $\mathrm{Na}^{+}$ conductance(Harrison et al., 1993; Kuo and Chen, 1999 ). Therefore, we speculated soluble zinc ions may not mainly contribute to the effects.

In summary, our results suggested that nano- $\mathrm{ZnO}$ solution may involve in 
depolarization-induced neuronal injury by activation of voltage-gated $\mathrm{Na}^{+}$channels, which lead to the enhancement of $\mathrm{Na}^{+}$influx, the accumulation of intracellular $\mathrm{Na}^{+}$, $\mathrm{Ca}^{2+}$ influx, and glutamate release, increasing the neuronal excitability. Additionally, the nano- $\mathrm{ZnO}$ could participate the neuronal apoptosis caused by the loss of cytoplasmic $\mathrm{K}^{+}$due to increased $\mathrm{K}^{+}$efflux through delayed rectifier potassium channels. The two possible mechanisms seemed associated with the dysfunction or deficiency of $\mathrm{Na}^{+}-\mathrm{K}^{+}$-ATPase, which was failure of maintenance of proper transmembrane ionic gradients.

\section{Acknowledgements}

This work was partly supported by the National Basic Research Program of China (2007CB914803) and National 863 Project (2008AA02Z129). 


\section{References}

Adams LK, Lyon DY, McIntosh A, Alvarez PJ. Comparative toxicity of nano-scale $\mathrm{TiO}_{2}, \mathrm{SiO}_{2}$ and $\mathrm{ZnO}$ water suspensions. Water Sci Technol 2006;54:327-34

Akasofu S, Sawada K, Kosasa T, Hihara H, Ogura H, Akaike A, Donepezil attenuates excitotoxic damage induced by membrane depolarization of cortical neurons exposed to veratridine. Eur $\mathbf{J}$ Pharmacol 2008;588:189-97

Arrebola F, Zabiti S, Canizares FJ, Cubero MA., Crespo PV, Fernandez-Segura E. Changes in intracellular sodium, chlorine and potassium concentrations in staurosporine- induced apoptosis. J Cell Physiol 2005;204:500-7

Beyersmann D, Haase H. Functions of zinc in signaling, proliferation and differentiation of mammalian cells. Biometals. 2001;14:331-41

Bortner CD, Cidlowski JA. Caspase independent/dependent regulation of $\mathrm{K}^{+}$, cell shrinkage, and mitochondrial membrane potential during lymphocyte apoptosis. J Biol Chem 1999;274:21953-62 Bortner CD, Cidlowski JA. Uncoupling cell shrinkage from apoptosis reveals that $\mathrm{Na}^{+}$influx is required for volume loss during programmed cell death. J Biol Chem 2003;278: 39176-84

Bortner CD, Hughes FM, Cidlowski JA. A primary role for $\mathrm{K}^{+}$and $\mathrm{Na}^{+}$efflux in the activation of apoptosis. J Biol Chem 1997;272:32436-42

Brayner R, Ferrari-Iliou R, Brivois N, Djediat S, Benedetti M.F, Fievet F. Toxicological impact studies based on Escherichia coli bacteria in ultrafine $\mathrm{ZnO}$ nanoparticles colloidal medium. Nano Lett 2006; 6(4):866-70

Brunner TJ, Wick P, Manser P, Spohn P, Grass RN, Limbach LK, Bruinink A, Stark WJ. In vitro cytotoxicity of oxide nanoparticles: Comparison to asbestos, silica, and the effect of particle solubility. Environ. Sci. Technol 2006;40:4374-81.

Chi XX, Xu ZC. Differential Changes of Potassium Currents in CA1 Pyramidal Neurons After Transient Forebrain Ischemia. J Neurophysiol 2000;84:2834-43

Choi DW. Calcium-mediated neurotoxicity: relationship to specific channel types and role in ischemic damage. Trends Neurosci 1988;11:465-9

Colvin VL. The potential environmental impacts of engineered nanomaterials. Nat Biotechnol 2003;21:1166-70

Denac H, Mevissen M, Scholtysik G. Structure, function and pharmacology of voltage-gated sodium channels. Naunyn-Schmiedeberg's Arch Pharmacol 2000;362:453-79

Dunford R, Salinaro A, Cai L, Serpone N, Horikoshi S, Hidaka H, Knowland J. Chemical Oxidation and DNA Damage Catalysed by Inorganic Sunscreen Ingredients. FEBS Lett 1997;418:87-90

Elder A, Gelein R, Silva V, Feikert T, Opanashuk L, Carter J, Potter R, Maynard A, Ito Y, Finkelstein J, 
Oberdörster G. Translocation of inhaled ultrafine manganese oxide particles to the central nervous system. Environ Health Perspect 2006;114:1172-8

Erecinska M, Silver IA. ATP and brain function. J Cereb Blood Flow Metab 1989;9:2-19

Fernandez-Segura E, Canizares FJ, Cubero MA, Warley A, Campos A. Changes in elemental content during apoptotic cell death studied by electron probe X-ray microanalysis. Exp Cell Res 1999;253: 454-62

Franklin NM, Rogers NJ, Apte SC, Batley GE, Gadd GE, Casey PS. Comparative Toxicity of Nanoparticulate $\mathrm{ZnO}$, Bulk $\mathrm{ZnO}$, and $\mathrm{ZnCl} 2$ to a Freshwater Microalga (Pseudokirchneriella subcapitata): The Importance of Particle Solubility.Environ Sci Technol 2007; 41(24): 8484-90

Friedman JE, Haddad GG. Anoxia induces an increase in intracellular sodium in rat central neurons in vitro. Brain Res 1994;663:329-34

Ghule K, Ghule A, Chen BJ, Ling YC. Preparation and characterization of ZnO nanoparticles coated paper and its antibacterial activity study. Green Chem 2006;8(12):1034-41

Harrison NL, Radke HK, Talukder G, ffrench-Mullen JMH. Zinc modulates transient outward current gating in hippocampal neurons. Receptors and Channels 1993;1(2):153-63

Heinlaan M, Ivask A, Blinova I, Dubourguier HC, Kahru A. Toxicity of nanosized and bulk ZnO, CuO and $\mathrm{TiO} 2$ to bacteria Vibrio fischeri and crustaceans Daphnia magna and Thamnocephalus platyurus. Chemosphere 2008; 71(7): 1308-16

Hughes Jr FM, Cidlowski JA. Potassium is a critical regulator of apoptotic enzymes in vitro and in vivo. Adv Enzyme Regul 1999;39:157-71

Jeng HA, Swanson J. Toxicity of metal oxide nanoparticles in mammalian cells. J Environ Sci Health A 2006;41(12):2699-711

Jiang C, Agulian S, Haddad GG. $\mathrm{Cl}^{-}$and $\mathrm{Na}^{+}$homeostasis during anoxia in rat hypoglossal neurons: Intracellular and extracellular in vitro studies. J Physiol 1991;448:697-708

Jing L Q, Xu Z L, Sun X J, Shang J, Cai WM. The surface properties and photocatalytic activities of ZnO ultrafine particles. Appl Surf Sci 2001;180:308-14

Judge SI, Smith PJ, Stewart PE, Bever CT Jr. Potassium Channel Blockers and Openers as CNS Neurologic Therapeutic Agents, Recent Patents CNS Drug Discov 2007;2:200-28

Kadekaro M, Crane AM, Sokoloff L, Differential effects of electrical stimulation of nerve on metabolic activity in spinal cord and dorsal root ganglion in the rat. Proc Natl Acad Sci USA 1985;82:6010-3

Krick S, Platoshyn O, Sweeney M, Kim H, Yuan JX-J. Activation of $\mathrm{K}^{+}$channels induces apoptosis in vascular smooth muscle cells. Am J Physiol Cell Physiol 2001;280:C970-9

Kumar SA, Chen SM. Nanostructured Zinc Oxide Particles in Chemically Modified Electrodes for Biosensor Applications. Analytical Letters 2008;41:141-58

Kuo CC and Chen FP. $\mathrm{Zn}^{2+}$ modulation of neuronal transient $\mathrm{K}^{+}$current: fast and selective binding to the deactivated channels. Biophys J 1999;77:2552-62 
Li Z, Yang RS, Yu M, Bai F, Li C and Wang ZL. Cellular Level Biocompatibility and Biosafety of ZnO Nanowires. J Phys Chem C. 2008 Nov 26, http://pubs.acs.org/doi/full/10.1021/jp808878p [Epub ahead of print]

Lockman PR, Koziara JM, Mumper RJ, Allen DD. Nanoparticle surface charges alter blood-brain barrier integrity and permeability. J Drug Target 2004;12:635-41

Lockman PR, Oyewumi MO, Koziara JM, Roder KE, Mumper RJ, Allen DD. Brain uptake of thiamine-coated nanoparticles. J Control Release 2003;93:271-82

Long TC, Tajuba J, Sama P, Saleh N, Swartz C, Parker J, Hester S, Lowry GV, Veronesi B. Nanosize titanium dioxide stimulates reactive oxygen species in brain microglia and damages neurons in vitro. Environ Health Perspect 2007;115:1631-7

Lynch JJ, Yu SP, Canzoniero LM, Sensi SL, Choi DW, Sodium channel blockers reduce oxygen-lucose deprivation-induced cortical neuronal injury when combined with glutamate receptor antagonists. J Pharmacol Exp Ther 1995;73:554-60

Martínez-Sánchez M, Striggow F, Schröder UH, Kahlert S, Reymann KG, Reiser G. $\mathrm{Na}^{+}$and $\mathrm{Ca}^{2+}$ homeostasis pathways, cell death and protection after oxygen-lucose deprivation in organotypic hippocampal slice cultures. Neuroscience 2004;28:729-40

Mathie A, Sutton GL, Clarke CE, Veale EL. Zinc and copper: Pharmacological probes and endogenous modulators of neuronal excitability. Pharmacol Ther 2006;11:567-83

McHugh PJ, Knowland J. Characterization of DNA Damage Inflicted by Free Radicals from a Mutagenic Sunscreen Ingredient and Its Location Using an in Vitro Genetic Reversion Assay. Photochem Photobiol 1997;66:276-81

Mitterdorfer J, Bean BP. Potassium Currents during the Action Potential of Hippocampal CA3 Neurons. J Neurosci 2002;22:10106 -15

Montague JW, Bortner CD, Hughes Jr FM, Cidlowski JA. A necessary role for reduced intracellular potassium during the DNA degradation phase of apoptosis. Steroids 1999;64:563-69

Nair S, Sasidharan A, Divya Rani VV, Menon D, Nair S, Manzoor K, Raina S.Role of size scale of $\mathrm{ZnO}$ nanoparticles and microparticles on toxicity toward bacteria and osteoblast cancer cells. J Mater Sci Mater Med. 2008 Aug 21. [Epub ahead of print]

Nel A, Xia T, Mädler L, Li N. Toxic potential of materials at nanolevel, Science 2006;311:622-7

Oberdorster G, Sharp Z, Atudorei V, Elder A, Gelein R, Kreyling W, Cox C. Translocation of inhaled ultrafine particles to the brain. Inhal Toxicol 2004;16:437-45

Panayiotidis MI, Bortner CD, Cidlowski JA. On the mechanism of ionic regulation of apoptosis: would the $\mathrm{Na}^{+} / \mathrm{K}^{+}$-ATPase please stand up? Acta Physiol 2006;187:205-15

Reddy KM, Feris K, Bell J, Wingett DG, Hanley C, Punnoose A. Selective toxicity of zinc oxide nanoparticles to prokaryotic and eukaryotic systems. Appl Phys Lett 2007; 90(213902): 2139021-3

Remillard CV, Yuan J X-J. Activation of $\mathrm{K}^{+}$channels: an essential pathway in programmed cell death. Am J Physiol Lung Cell Mol Physiol 2004;286:L49-67 
Sayes CM, Reed KL, Warheit DB. Assessing toxicity of fine and nanoparticles: comparing in vitro measurements to in vivo pulmonary toxicity profiles. Toxicol Sci 2007;97(1):163-80

Segal M, Rogawski MA, Barker JL. A transient potassium conductance regulates the excitability of cultured hippocampal and spinal neurons. J Neurosci 1984;4:604-9

Serpone N, Dondi D,Albini A. Inorganic and organic UV filters: Their role and efficacy in sunscreens and suncare products, Inorg Chim Acta 2007;360:794-802

Stys PK. Anoxic and ischemic injury of myelinated axons in CNS white matter: from mechanistic concepts to therapeutics. J Cereb Blood Flow Metab 1998;18:22-5

Takahashi S, Shibata M, Fukuuchi Y. Role of sodium ion influx in depolarization- induced neuronal cell death by high KCI or veratridine. Eur J Pharmacol 1999;372:297-304

Takahashi S, Shibata M, Gotoh J, Fukuuchi Y. Astroglial cell death induced by excessive influx of sodium ions. Eur J Pharmacol 2000;408:127-35

Takano H, Fukushi H, Morishima Y, Shirasaki Y. Calmodulin and calmodulin-dependent kinase II mediate neuronal cell death induced by depolarization. Brain Res 2003;962:41-7

Takeda A, Suzuki M, Oku N. Possible involvement of plasma histidine in differential brain permeability to zinc and cadmium. Biometals 2002;15:371-5

Takeda A. Zinc homeostasis and functions of zinc in the brain. Biometals 2001;14: 343-51

Tam KH, Djurišić AB, Chan CMN, Xi YY, Tse CW, Leung YH, Chan WK, Leung FCC and Au DWT. Antibacterial activity of $\mathrm{ZnO}$ nanorods prepared by a hydrothermal method. Thin Solid Films 2008;516(18):6167-74

Tarnawa I, Bölcskei H, Kocsis P. Blockers of voltage-gated sodium channels for the treatment of central nervous system diseases. Recent Patents CNS Drug Discov 2007;2:57-78

Taylor CP, Meldrum BS. $\mathrm{Na}^{+}$channels as targets for neuroprotective drugs. Trends Pharmacol Sci 1995;6:309-16

Thompson GJ, Langlais C, Cain K, Conley EC, Cohen GM. Elevated extracellular $\left[\mathrm{K}^{+}\right]$inhibits death-receptor- and chemical-mediated apoptosis prior to caspase activation and cytochrome c release. J Biochem 2001;357:137-45

Vu CCQ, Bortner CD, Cidlowski JA. Differential involvement of initiator caspases in apoptotic volume decrease and potassium efflux during Fas- and UV-induced cell death. J Biol Chem 2001;276:37602-11

Wang B, Feng WY, Wang M, Wang T C, Gu Y Q, Zhu M T, Ouyang H, Shi J W, Zhang F, Zhao Y L, Chai Z F, Wang H F, Wang J, Acute toxicological impact of nano- and submicro-scaled zinc oxide powder on healthy adult mice. J Nanopart Res 2008;10(2):263-76

Wang ZL. Splendid One-Dimensional Nanostructures of Zinc Oxide: A New Nanomaterial Family for Nanotechnology. ACS Nano 2008; 2(10): 1987-92

Xiao AY, Wei L, Xia S, Rothman S, Yu SP. Ionic mechanism of ouabain-induced concurrent apoptosis 
and necrosis in individual cultured cortical neurons. J Neurosci 2002;22:1350-62

Xu LJ, Zhao JX, Zhang T, Ren GG, Yang Z. In vitro study on influence of nano particles of $\mathrm{CuO}$ on CA1 pyramidal neurons of rat hippocampus potassium currents. Environ Toxicol 2008 Jul 11. [Epub ahead of print]

Yamamoto O, Komatsu M, Sawai J, Nakagawa ZE. Effect of lattice constant of zinc oxide on antibacterial characteristics. J. Mater. Sci., Mater. Med. 2004;15 (8):847-51

Yu SP, Yeh C-H, Gottron F, Wang X, Grabb MC, and Choi DW. Role of the outwardly delayed rectifier $\mathrm{K}$ current in ceramide-induced caspase activation and apoptosis in cultured cortical neurons. J Neurochem 1999;73:933-41

Yu SP, Yen C-H, Sensi SL, Gwag BJ, Canzoniero LMT, Farhangrazi ZS, Ying HS, Tian M, Dugan LL, Choi DW. Mediation of neuronal apoptosis by enhancement of outward potassium current. Science 1997;278:114-7

Yu SP. $\mathrm{Na}^{+}, \mathrm{K}^{+}$-ATPase: The new face of and old player in pathogenesis and apoptotic/hybrid cell death. Biochem Pharmacol 2003;66:1601-9

Yuranova T, Laub D, Kiwi J. Synthesis, activity and characterization of textiles showing self-cleaning activity under daylight irradiation. Catal Today 2007;122:109-17

Zhang L, Jiang Y, Ding Y, Povey M and York D, Investigation into the antibacterial behaviour of suspensions of ZnO Nanoparticles (ZnO nanofluids), J. Nanopart Res 2007; 9:479-89

Zhu X, Zhu L, Duan Z, Qi R, Li Y, Lang Y. Comparative toxicity of several metal oxide nanoparticle aqueous suspensions to Zebrafish (Danio rerio) early developmental stage. J Environ Sci Health A 2008; 43(3):278-84

Zou BD, Chen YZ, Wu CH, Zhou PA. Blockade of U50488H on sodium currents in acutely isolated mice hippocampal CA3 pyramidal neurons. Brain Res 2000;855:132-6 
Table 1 Effects of nano-ZnO on properties of single action potential and number of APs in repetitive firing

\begin{tabular}{ccccc}
\hline & peak amplitude $(\mathrm{mV})$ & overshoot $(\mathrm{mV})$ & spike half-width $(\mathrm{ms})$ & number of APs \\
\hline control & $94.07 \pm 2.15$ & $24.07 \pm 2.15$ & $2.62 \pm 0.31$ & $13.83 \pm 0.48$ \\
nano-ZnO & $103.37 \pm 2.19^{* *}$ & $33.37 \pm 2.19^{* *}$ & $2.29 \pm 0.24^{*}$ & $15.50 \pm 0.76^{*}$ \\
\hline
\end{tabular}

Significance levels are given as $\mathrm{P}<0.05(*)$ and $\mathrm{P}<0.01(* *)$ for differences from control. $\mathrm{n}=6$. 


\section{Figure Legends}

Fig.1. TEM image of nano-scaled $\mathrm{ZnO}$.

Fig.2. Effect of $10^{-4} \mathrm{~g} / \mathrm{ml}$ nano- $\mathrm{ZnO}$ on sodium currents $\left(\mathrm{I}_{\mathrm{Na}}\right)$. (A) Currents were obtained by $20 \mathrm{~ms}$ depolarizing pulses from holding potential of -100 to $+60 \mathrm{mV}$ at 10 $\mathrm{mV}$ steps.(B) The current-voltage curves of $\mathrm{I}_{\mathrm{Na}}$. (C) The steady-state activation curves of $\mathrm{I}_{\mathrm{Na}}$, peak amplitudes of $\mathrm{I}_{\mathrm{Na}}$ were converted into conductance by using the equation $\mathrm{G}=\mathrm{I} /\left(\mathrm{V}_{\mathrm{m}}-\mathrm{V}_{\mathrm{r}}\right)$, normalized conductance of sodium channels were plotted against the voltages of conditioning pulses, and fitted with a Boltzmann function. Each point represents mean $\pm \operatorname{SEM}(\mathrm{n}=11, * \mathrm{P}<0.05$ and $* * \mathrm{P}<0.01$ vs control $)$.

Fig.3. Effect of $10^{-4} \mathrm{~g} / \mathrm{ml}$ nano- $\mathrm{ZnO}$ on inactivation kinetics of $\mathrm{I}_{\mathrm{Na}}$. Currents were elicited with a $20 \mathrm{~ms}$ depolarizing pulse to $-10 \mathrm{mV}$ preceded by $50 \mathrm{~ms}$ prepulses to potentials between -100 and $-10 \mathrm{mV}$ in $5 \mathrm{mV}$ increments, and holding potential at $-100 \mathrm{mV}$. (A)and (B) are steady-state inactivation of $\mathrm{I}_{\mathrm{Na}}$ before and after application of nano- $\mathrm{ZnO}$; (C) is the expanded traces taken from (A). (D) The steady-state inactivation curves of $\mathrm{I}_{\mathrm{Na}}$. Peak amplitudes for $\mathrm{I}_{\mathrm{Na}}$ currents were normalized and plotted vs prepulse potentials, and the data are fitted with Boltzmann function. Each point represents mean \pm SEM $(n=8)$. The values of $V_{h}$ for inactivation of $I_{N a}$ before and after addition of nanoparticle $\mathrm{ZnO}$ are $-52.54 \pm 0.43 \mathrm{mV}$ and $-54.67 \pm 0.39 \mathrm{mV}$ $(\mathrm{P}<0.01)$.

Fig.4. Effect of $10^{-4} \mathrm{~g} / \mathrm{ml}$ nano- $\mathrm{ZnO}$ on recovery from inactivation of $\mathrm{I}_{\mathrm{Na}}$. (A) The currents were obtained as followed protocol: holding potential at $-90 \mathrm{mV}$, a $50 \mathrm{~ms}$ conditioning depolarizing pulse of $-40 \mathrm{mV}$ was applied to inactivate the sodium channels fully, and then a $50 \mathrm{~ms}$ test pulse of $-40 \mathrm{mV}$ was applied after a series of -90 $\mathrm{mV}$ intervals varying from 2 to $36 \mathrm{~ms}$ (in $2 \mathrm{~ms}$ increments). (B) The recovery from inactivation curves of $\mathrm{I}_{\mathrm{Na}}$. The peak value of $\mathrm{I}_{\mathrm{Na}}$ evoked by the conditioning pulse was designated as $\mathrm{I}_{1}$, while the peak value of $\mathrm{I}_{\mathrm{Na}}$ evoked by the test pulse was designated as $I_{2}$. The ratio of $I_{2}$ to $I_{1}$ represents the recovery of $I_{N a}$ from inactivation. The plot of $\mathrm{I}_{2} / \mathrm{I}_{1}$ vs the duration of the $-90 \mathrm{mV}$ intervals was fitted with a monoexponential function. Each point represents mean $\pm \operatorname{SEM}(n=8)$. The time constants $(\tau)$ for recovery from inactivation of $\mathrm{I}_{\mathrm{Na}}$ before and after addition of nano-ZnO were $5.40 \pm$ $0.19 \mathrm{~ms}$ and $3.95 \pm 0.15 \mathrm{~ms}(\mathrm{P}<0.01)$.

Fig.5. Effect of $10^{-4} \mathrm{~g} / \mathrm{ml}$ nano- $\mathrm{ZnO}$ on $\mathrm{I}_{\mathrm{A}}$ and $\mathrm{I}_{\mathrm{K}}$. (A) and (B): $\mathrm{I}_{\mathrm{A}}$ and $\mathrm{I}_{\mathrm{K}}$ were obtained 
by $80 \mathrm{~ms}$ and $160 \mathrm{~ms}$ depolarizing pulses respectively, from a command potential of -50 to $+90 \mathrm{mV}$ in increments of $10 \mathrm{mV}$, and the holding potential was $-70 \mathrm{mV}$. (C) and (D): The current-voltage curve of $\mathrm{I}_{\mathrm{A}}$ and $\mathrm{I}_{\mathrm{K}}$. $(\mathrm{E})$ and $(\mathrm{F})$ : The steady-state activation curves of $I_{A}$ and $I_{K}$. Peak amplitudes of $I_{A}$ and $I_{K}$ were converted into conductance by using the equation $\mathrm{G}=\mathrm{I} /\left(\mathrm{V}_{\mathrm{m}}-\mathrm{V}_{\mathrm{r}}\right)$, normalized conductance of potassium channels were plotted against the voltages of conditioning pulses, and fitted with a Boltzmann function. Each point represents mean $\pm \operatorname{SEM}(n=6, * P<0.05$ vs control)

Fig.6. Effect of $10^{-4} \mathrm{~g} / \mathrm{ml}$ nano- $\mathrm{ZnO}$ on inactivation kinetics of $\mathrm{I}_{\mathrm{A}}$. (A)Currents were elicited with a $80 \mathrm{~ms}$ depolarizing pulse to $+50 \mathrm{mV}$ preceded by $80 \mathrm{~ms}$ prepulses to potentials between -120 and $+10 \mathrm{mV}$ in $10 \mathrm{mV}$ increments, and holding potential at $-70 \mathrm{mV}$.(B) The steady-state inactivation curves of $\mathrm{I}_{\mathrm{A}}$. Peak amplitudes for $\mathrm{I}_{\mathrm{A}}$ currents were normalized and plotted vs prepulse potentials, and the data are fitted with Boltzmann function. Each point represents mean \pm SEM $(n=6)$.

Fig.7. Effect of $10^{-4} \mathrm{~g} / \mathrm{ml}$ nano- $\mathrm{ZnO}$ on recovery from inactivation of $\mathrm{I}_{\mathrm{A}}$. (A) The currents were obtained as followed protocol: holding potential at $-70 \mathrm{mV}$, an $80 \mathrm{~ms}$ conditioning depolarizing pulse of $+50 \mathrm{mV}$ was applied to inactivate the transient outward potassium channels fully, and then an $80 \mathrm{~ms}$ test pulse of $+50 \mathrm{mV}$ was applied after a series of $-80 \mathrm{mV}$ intervals varying from 10 to $260 \mathrm{~ms}$ (in $10 \mathrm{~ms}$ increments). (B)The recovery from inactivation curves of $I_{A}$. The peak value of $I_{A}$ evoked by the conditioning pulse was designated as $\mathrm{I}_{1}$, while the peak value of $\mathrm{I}_{\mathrm{A}}$ evoked by the test pulse was designated as $I_{2}$. The ratio of $I_{2}$ to $I_{1}$ represents the recovery of $I_{A}$ from inactivation. The plot of $I_{2} / I_{1}$ vs the duration of the $-80 \mathrm{mV}$ intervals was fitted with a monoexponential function. Each point represents mean \pm $\operatorname{SEM}(n=6)$.

Fig.8. Effect of nano- $\mathrm{ZnO}$ on evoked single action potential. Single action potential was elicited by brief depolarizing current pulses ( $5 \mathrm{~ms}, 100 \mathrm{pA})$ from a holding potential of $-70 \mathrm{mV}$.

Fig.9. Effect of nano- $\mathrm{ZnO}$ on repetitive firing evoked by a prolonged depolarizing current injection $(500 \mathrm{~ms}, 50 \mathrm{pA}$ ) from a holding potential of $-70 \mathrm{mV}$. 